\title{
ICT Integration in Preschool Classes: Examples of Practices in Greece
}

\author{
Kleopatra Nikolopoulou \\ Faculty of Early Childhood Education, School of Education, University of Athens, Athens, Greece \\ Email: klnikolopoulou@ath.forthnet.gr
}

Received 24 January 2014; revised 24 February 2014; accepted 4 March 2014

Copyright (C) 2014 by author and Scientific Research Publishing Inc.

This work is licensed under the Creative Commons Attribution International License (CC BY).

http://creativecommons.org/licenses/by/4.0/

(c) (i) Open Access

\section{Abstract}

This paper presents findings from a research project regarding Information and Communication Technology (ICT) integration and use in 17 kindergartens in Greece. The main parameters of the study were the natural classroom environment (without artificial intervention) and the voluntary participation of early childhood teachers. The data were collected by interviews with the teachers and class observations. The most frequently reported reasons for computer use were the acquisition/ development of language and fine motor skills, as well as its contribution as an incentive in children's learning. Examples of practices in relation to these reasons are presented. The computer was mainly used during the hour of free activities. The role of early childhood teachers, in the whole process of ICT integration, is also discussed.

\section{Keywords}

ICT (Information and Communication Technology), Computer, Preschool, Kindergarten, Greece

\section{Introduction}

While relatively little research has been undertaken with young children aged under seven years using Information and Communication Technology (ICT) and research evidence may be unclear, there is a growing recognition of the impact of ICT on children's lives, particularly from the USA (Haugland \& Wright, 1997; Labbo et al., 2003; Clements \& Sarama, 2003; Roskos et al., 2011; Parette \& Blum, 2013), Australia (Yelland, 2005; Yelland \& Kilderry, 2010; Zevenbergen \& Logan, 2008; Verenikina et al., 2010), the UK (Stephen \& Plowman, 2003; Siraj-Blatchford \& Siraj-Blatchford, 2006; Morgan, 2010) and the Netherlands (Segers \& Verhoeven, 2002; McKenney \& Voogt, 2012), for example. These, as well as other research studies (e.g., McCarrick \& Li, 2007; Shawareb, 2011), have indicated that computer can be used as a tool to support learning, and assist communication, collaboration, creativity and language development in young children. Recognizing that there is a wide 
range of technology applications available to young children, the issue is not, whether technology should be considered and used in early childhood education settings, but how and whether it makes a difference in children's learning and development (Parette et al., 2010). However, there is limited research on why and how young children use technology/ computers (or widely ICT) in kindergarten classrooms (e.g. Plowman \& Stephen, 2003; Judge et al., 2006; McKenney \& Voogt, 2010). Recently, in the USA, the National Association for the Education of Young Children and the Fred Rogers Center reported that "developmentally appropriate practices must guide decisions about whether and when to integrate technology and interactive media into early childhood programs” (NAEYC-FRC, 2012: p. 5). This report emphasizes that technology can enhance early childhood practice when integrated into the curriculum and daily kindergarten routines.

Regarding the ways of using computers in kindergarten/preschool classes, it can be used, among others, as an available option or as an essential activity (Ljung-Djärf et al., 2005). Computer use is often something that may be allowed between planned or adult-led activities, which means that it is typically used during the time that is organised as free play (Ljung-Djärf, 2008). In discussing computer use in kindergarten classes, the phrase "playing with the computer" is often used by teachers and children (e.g., Plowman \& Stephen, 2005): designating a series of qualitatively different activities (associated with different types of software including computer games) in which children may, for example, engage in exercise control, play or create. When computer use takes place within kindergarten classes, the role of adult/teacher intervention in supporting and extending children's experiences has been emphasized (e.g., Nir-Gal \& Klein, 2004; McKenney \& Voogt, 2012), while some studies have shown that children are largely left alone at the computer and the teachers seldom participate in what goes on there (Plowman \& Stephen, 2005). As evidence-based guidelines for computer use in preschool education are limited (Siraj-Blatchford \& Siraj-Blatchford, 2006), it is rather uncertain for teachers on how to achieve the visions-claims reported in literature. Investigating early childhood teachers' reasons as to why they use computers is essential because their reasons affect their classroom practices (Dennis, 2009; Kervin \& Mantei, 2009). In parallel, investigating the ways of computer integration-use in kindergarten classes is useful, as there are not currently many empirical studies from different countries.

This paper presents examples of practices regarding ICT integration and use in kindergarten classes, in Greece. In this paper, the term computer(s) is used as synonymous to the term ICT (Information and Communication Technology). Today's children meet a wide range of technology in their everyday lives and they become competent users of devices such as mobile phones, games machines and communication-based devices (Morgan \& Kennewell, 2005; Rosen \& Jaruszewicz, 2009), while there is an agreement that today, children are using computers even before they know how to read and write (McKenney \& Voogt, 2010). Mobile learning devices such as small multimedia, multifunction hand-held devices, as well as voice controls, sensors and digital interfaces which use touch or eye/ear attachments will become the future for young children (Kennington \& Meaton, 2009). Apart from computer software, a number of products that incorporate some aspect of ICT are available to young children such as digital cameras, console games, MP3 microphones and programmable toys. However, practitioners define ICT more narrowly as computers and printers and this view is very influential (Stephen \& Plowman, 2003) till now. In this study, the terms preschool, kindergarten and early childhood setting are used as synonymous, and they refer to formal educational settings that attend children above three years old.

\section{Method}

\subsection{Research Overview}

The aim of the research project was to investigate the reasons and the ways of computer integration-use in kindergarten classes, in Athens, Greece. Three basic parameters of the study were: 1) the presence of at least one computer in the kindergarten classroom and its use by preschool children, 2) the voluntary participation of kindergarten teachers and 3) the study to be carried out without artificial intervention by the researcher (i.e., into the "natural" classroom environment). The investigation included 17 state kindergartens. For the purpose of this research, official permission was provided by the research department of the Greek Pedagogical Institute and all kindergarten schools and subjects were treated anonymously.

\subsection{Ethical Considerations}

Regarding ethical considerations, kindergarten teachers were informed about the nature, duration and the aim of 
this research study. Ethical issues arise when investigating dependent, vulnerable members of society such as young children in early childhood education settings, thus research in these settings (e.g. Morgan, 2010) needs to take into account ethical issues. Gaining informed consent from research participants is widely regarded as central to ethical research practice and in institutional settings such as schools, access tends to be mediated by teachers, managers etc. (Heath et al., 2007). Issues of anonymity and confidentiality are also included in ethical considerations. Such parameters-conditions were assured in this study: all kindergartens and their subjects were replaced with codes and participants' names were changed in written accounts. Additionally, as research suggests (Flewitt, 2005), initial and ongoing consent with teachers was negotiated and participants were informed about research outcomes. As visual methods of data collection (e.g. video recordings) were not used in this study (due to tight finances), ethical dilemmas regarding visual data represention did not arise.

\subsection{Sample}

Twenty three classes from 17 different kindergartens in Greece participated in this study. Initially, according to the parameters of the study, there was at least one computer in the kindergarten classroom and this was used by the children. The kindergarten teachers were all women and agreed 1) to participate voluntarily in the research study and 2) for the study to be carried out in the natural classroom environment (i.e., without artificial intervention by the researcher). The kindergartens were situated in the urban city of Athens, they were all state schools (not private) serving children 4 - 6.5 years old. However, the majority of the children were aged 5 - 6.5 years old as kindergarten attendance in Greece is now obligatory only for this age group. Classes held between 13 - 26 children.

\subsection{Data Collection Process and Research Instruments}

Data were collected between January 2009 and June 2010 and consisted of interviews with the teachers (based on specific axes), observations of class activities and examples of children's work. Interviews can reveal the "why" and "how" of the teaching and learning processes, while researchers may observe interactions between children, computers and the teacher (Forman \& Hall, 2005). Qualitative approaches seem practical for younger children and although they include small samples and are not easily generalisable, they are valuable in early childhood education settings (Nikolopoulou, 2010). The semi-structured interviews with the teachers were conducted before the observation sessions, were audio-recorded and were based on specific axes related to the research objectives.

In parallel with the interviews, in each kindergarten were conducted two to three observations of ICT use of total duration of 1.5 to 2.5 hours (i.e., two to three sessions, each one in a different day) and field notes of what took place around the computer(s) were made. All observations took place from January onwards, after negotiation with the teachers. This time period, being three months after the commencement of the academic year, was proposed by the teachers because they wanted their children to be initially acquainted to the new kindergarten environment before any research took place. As mentioned earlier, an essential aspect of this research study was to be carried out without an imposed intervention by the researcher. Thus, the timing for the observations, and the activities in the classes were all decided by the class teachers.

\section{Results-Examples of Practices in Kindergarten Classes}

Table 1 displays the reasons for using the computer in kindergarten classes, as these were articulated-reported by the kindergarten teachers.

Most teachers referred to the acquisition/development of language skills and fine motor skills, as well as the computer use as an incentive-motivation for learning. Then, they mentioned computer use as a supervisory teaching tool and as a means for children's entertainment.

The way educational software was used in kindergarten classes, as well as the educational software commonly used were reported in another paper (Nikolopoulou, 2014). It was found that computer use took place, mainly, during the hour of free activities/play. The frequency of computer use, for each child, was found to vary between 2 - 3 times per week and once per month. However, most teachers reported that every child is entitled (if s/he wants) to work on the computer once per week, with an average time of use 10 - 20 minutes. The most commonly used programs were the MS Paint, commercial and educational CD-ROMs and the MS Word. 
Table 1. Reasons for using the computer with the children.

\begin{tabular}{|c|c|}
\hline Reasons for using the computer & No. of references \\
\hline acquisition/ development of language skills (reading, writing) & 8 \\
\hline acquisition/ development of fine motor skills & 8 \\
\hline incentive - motivation for learning (or as a reward) & 8 \\
\hline supervisory teaching tool & 7 \\
\hline for entertainment (e.g. for playing games) & 6 \\
\hline to support the objectives of the (Greek) programme of studies & 5 \\
\hline development of mathematical skills & 5 \\
\hline searching/ finding information (e.g. for a project) & 3 \\
\hline creation of a CD-ROM (documenting children's work, class activities e.t.c.) for the parents & 2 \\
\hline consolidation of the work that has started & 1 \\
\hline
\end{tabular}

The main reasons for using the computer in class (together with aspects of computer use in class) are discussed below, via presentation of examples of practices in different classes. The overall discussion takes place in the last section.

\subsection{Acquisition/Development of Language Skills}

As articulated by some teachers the computer is frequently used for the development of language skills, such as reading and writing. For example, in preschool 1, this is done via different activities, one of them being the "newspaper publication". In this preschool the computers are mainly used during the "hour of free activities" (one hour every noon, after lunch). In general, each child uses the computer two to three times a week, according to the tasks. The children work in pairs they choose by themselves: whoever chooses the computer corner must write his/her name and the date in a small diary kept beside each computer (a procedure followed for each free activity). During class observations the researcher-observer and author of this paper observed two children working at the computer corner. They worked under their teacher's guidance for the class' newspaper: the aim was to produce one newspaper sheet (one page sized A4) each month, covering the activities of the month. One day, the teacher chose two boys who had advanced literacy skills in comparison to other children, and gave them the task of writing two short sentences as an explanation of a photograph taken in an interview with a parent (the unit being studied at that period regarded profession). The content of the sentences, as well as help for the correct spelling, was done in co-operation with the teacher. Another day, the work on the newspaper continued with the teacher showing and directing three girls on how to produce a scanned image of their drawing (it regarded the visit of a child's mother-policewoman - in the preschool). When the teacher imported children's scanned drawing in the newspaper file, the children were very enthusiastic. An indicative excerpt from the interview with the teacher of preschool A was: "The computer is used (in class) in order for the children to develop language skills, through activities such as searching the internet, publishing a newspaper and writing...Children learn quickly to recognize and write their name”.

In another preschool (preschool 4) the researcher observed two children who used the program MS Word in order to write a short story (on one computer) and a vocabulary (on the other computer), both related to a specific letter of the alphabet: children were asked to copy what was written on a cardboard. As teachers explained, computer work followed various writing and recognizing letters off-computer activities, and the teachers provided guidance and intervention (e.g., for showing specific functions of the Word). As articulated by the teachers, the computers are used to support learning goals, according to curriculum, in different subjects such as language and mathematics, for the development of skills (e.g., via using a painting program), for entertainment, and as a motivator for children. The computers are mainly used during the "hour of free activities". Access to the computer in the classroom is scheduled, where each child is assigned a post a particular day of the week (if s/he wishes to do so): otherwise, the child looses his/her turn and no other child is allowed to take her/his computer post. During observations, the children worked under teacher guidance, relevant language off-computer activities preceded computer work, and the computer was used to complement language learning goals.

Additionally, another commonly met practice in different schools was for children to write their name (in MS 
Word) and then print it. For example, in preschool 14, as soon as children arrive in class every morning, they sit at the computer corner and write their name.

\subsection{Acquisition/Development of Fine Motor Skills}

As many teachers articulated, the computer is often used for the development of children's fine motor skills. For this reason children often are left to play games, mainly on their own without any teacher supervision.

Indicative excerpts referring to computer use for the development of fine motor skills, were: (i) "Initially (during the first months of using the computer in class), we use the computer for hand-eye coordination and for the development of fine motor skills" (teachers in preschool 6), (ii) "We use the computer, mainly, for the familiarization of the children with the mouse and the keyboard. Then, we watch several images on the internet and in this way it (the computer) acts more as a supervisory teaching tool" (teacher in preschool 9), and (iii) "The computer is used for the development of fine motor skills, via activities carried out when using the programs Word and Paint" (teacher in preschool 10). It has to be stressed that many games are educational and apart from practicing fine motor skills, children can learn mathematics (or another subject). For example, in Figure 1, children practice the concepts "greater than" and "less than".

\subsection{Incentive-Motivation for Learning}

The computer is also used as an incentive-motivator for children who under different circumstances do not show interest. For example, in preschool 11 when a child completes an activity, s/he is allowed, as a reward, to sit at the computer corner and play the game s/he likes. An excerpt from the interview with the teachers in preschool 4, refers to computer use for the development of language skills and also its use as an incentive-motivation for learning: "The computer initiates children's interest, for instance, in the context of teaching a specific letter of the alphabet: Children listen to a story and they are asked to identify two words (from the story) beginning with that specific letter and then the child who answers correctly goes to the computer to write down the words that has just identified".

It is obvious, that the computer is used for a combination of different reasons in the preschool classes. For example, as articulated by a teacher in preschool 12, the computer is used to support and complement a task that has started (e.g., in combination with writing or mathematics activities), to assist in working towards learning goals, to motivate and engage more children (in comparison to traditional methods), so providing greater access to curriculum. Other reasons included computer use for the creation of a CD-ROM, documenting children's work, for distribution to parents. For example, during an observation in preschool 8, the teacher guided step-bystep two children, for creating-naming folders (with their name) and copying into them various files from the hard disk: files related to the individual child, such as children's paintings done with the Paint program and digital photographs of class activities. The aim was for this task to be done with every child, in order to then create

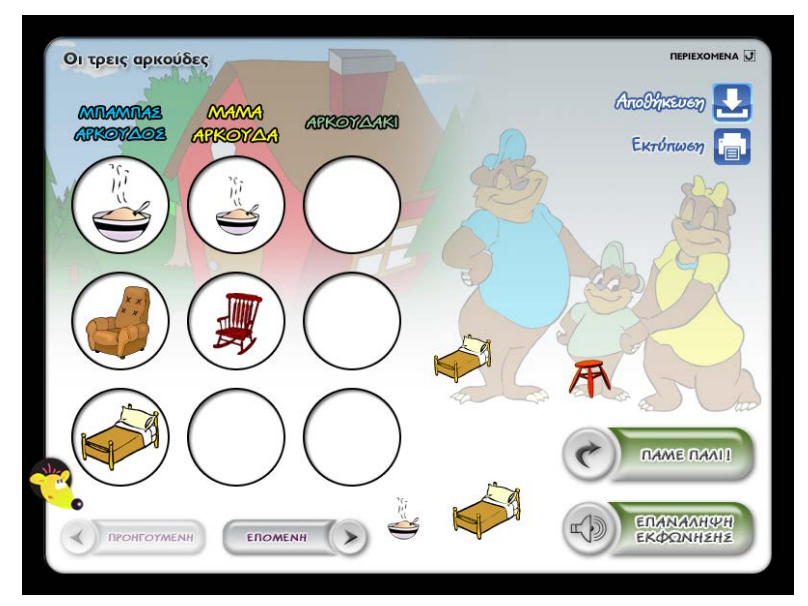

Figure 1. Print screen from the software "Computer's Explorer" (the children are asked to place in order the three bears' objects). 
a unique CD-ROM for each child's family. In another preschool there is a digital portfolio (including the child's work throughout the academic year), which is given to each child's parents at the end of the year.

\section{Discussion}

The data derived from the seventeen kindergartens in Greece cannot be generalized due to the small sample and its origin from one region. However, the class observations and the interviews with the teachers revealed some issues difficult to be explored through large-scale quantitative surveys. The most commonly reported reasons for using the computer in kindergarten classes were computer's support in the acquisition/development of various skills (mainly language and fine motor skills) and its contribution as an incentive in children's learning. Computer use was reported to be a powerful incentive for some children and, in particular, the software's feature of providing a score seemed to be an incentive for keeping children on the task. This is in agreement with the literature which reported that computers provide a highly motivating opportunity to learn for young children, while children demonstrate active interest and joy (Liu, 1996; Ljung-Djärf et al., 2005; McCarrick \& Li, 2007). The reasons given by the teachers, as well as the activities-tasks carried out by the children were, in general, in agreement with the suggestions of the Greek programme of studies (YPEPTH-P.I., 2003): according to which children can develop skills (such as language, mathematics and fine motor skills) via different learning activities that embed computer use. Teachers reported reasons that are related to visions formulated at the political level. However, the Greek official programme of studies (government policy document) does not provide adequate guidance for teachers in order to successfully integrate ICT use in their classes.

Regarding the way(s) of computer integration-use, all kindergartens had the computer corner; computer use was reported to take place (mainly) daily in the hour of free activities/play and the choice to use the computer or not was largely up to the child. Literature refers to computer integration in kindergarten's daily practice so that children can understand its contribution towards teaching and learning (Komis, 2004; Plowman \& Stephen, 2003). Ljung-Djärf et al. (2005) and Ljung-Djärf (2008) found that computer use happened during the free play activities, while the role of the teacher varied from low to high participation in accordance to whether the activities were voluntary or obligatory (in particular, when children played computer games they were mainly left alone and the teacher rarely intervened). In this study, although computer use took place during the hour of free activities, it was observed that teachers' practices (e.g. guidance) did vary. For example, in preschools 1 and 4 computer use was observed to follow non-computer activities in order to support an early learning goal, a fruitful practice that leads to better learning outcomes according to Haugland (1992). Computer activities of young learners should be integrated with related classroom activities (Van Scoter, 2008). In some cases, where one teacher had under her care over twenty children (e.g. in preschools 2 and 10), this did not appear to constitute an obstacle for the provision of guidance. This can be explained by the fact that the computer was used during the hour of free play/activities and only a small number of children (around $2-5$, depending on the number of class computers and the children who chose the computer corner) were using simultaneously the class computer(s), with the rest of the class to be engaged in other activities (such as painting, building blocks) which did not "demand" great teacher guidance. Thus, the class teacher either guided the very few children on the computer tasks or she was always available to help them when needed. Teacher guidance-mediation as revealed during the class observations, varied from careful guidance for teaching new concepts/skills to assistance whenever children asked for it, and these types of teacher guidance are discussed by researchers (e.g., Plowman \& Stephen, 2005). The maintenance of a reference plan (as it occurred in about half of the kindergartens) was found to be a useful way for recording children's access to the computer. Existing ways of teachers' acting constitute different kindergarten practices. Such environments afford different possibilities for children to learn about the computer or through its use (an issue for further research).

This study's findings revealed the essential role of the teacher in the whole process of computer integrationuse in kindergarten classes. It was a prerequisite for the project to be conducted in the normal classroom environment, without having an imposed (artificial) intervention by the researcher. The teachers participated voluntarily, they decided on the timing and the way of computer use in their classes, as well as on the class organization. Computers have the potential to support young children's classroom experiences, but for this to happen "it is necessary for teachers to carefully plan for, and articulate to children, suitable classroom tasks" (Kervin \& Mantei, 2009, p. 30). It was observed that when the computer was used during the hour of free activities, it was not necessarily selected (or selected by the same frequency) by all children, an issue that should be taken into 
account by teachers. As there is very little research-based guidance on the use of computers in early childhood settings (Siraj-Blatchford \& Siraj-Blatchford, 2006; Plowman \& Stephen, 2005; Yelland \& Kilderry, 2010), for example, what are appropriate teacher practices and how ICT can be effectively used to facilitate children's learning and development, are important issues needed further investigation.

The vital importance of teacher's role towards more effective ICT/technology integration in kindergarten classes has implications for teacher training. Early childhood teacher educators provide a critical link in helping the early childhood field move into the 21st century and they should take the lead in preparing future teachers to use technology with children in responsible and developmentally appropriate ways (Rosen \& Jaruszewicz, 2009). Research (Parette et al., 2010; Parette \& Blum, 2013; Keengwe \& Onchwari, 2009; Olney et al., 2008) indicated that both preservice education and in-service professional development need to emphasize appropriate uses and ways of integrating technology in early childhood settings. Early childhood teachers' technology skills, their abilities to integrate technology effectively and their beliefs are all important in the process of computer integration-use in kindergartens (Judge et al., 2006). For example, as in Greece there is little experience in designing educational scenarios involving ICT integration (Mikropoulos \& Bellou, 2010), teachers’ pedagogical training in ICT can assist in designing and implementing educational scenarios by incorporating appropriate software in kindergarten classes. The second phase of the current in-service teacher training programme in Greece includes teachers' familiarisation and use of appropriate software programs, designing of scenarios and use of Web2.0 tools; this programme is expected to be gradually attended by a number of kindergarten teachers.

\section{Conclusion}

The most commonly reported reasons for using the computer in kindergarten classes were computer's support in the acquisition/development of various skills (mainly language and fine motor skills) and its contribution as an incentive in children's learning. Regarding the way(s) of computer integration-use, all kindergartens had the computer corner; computer use was reported to take place (mainly) daily in the hour of free activities/play and the choice to use the computer or not was largely up to the child.

The essential role of the teacher in the whole process of computer integration-use in kindergarten classes, was revealed in this study. It was a prerequisite for the project to be conducted in the normal classroom environment, without having an imposed (artificial) intervention by the researcher. The teachers participated voluntarily, and they decided on the timing and the way of computer use in their classes, the software used, as well as on the class organization.

Digital technologies (broadly ICT) are constantly/rapidly changing and they are becoming part of children's sociocultural experiences outside formal educational settings. Today's children, born into the digital world, are called "digital natives" as they are native speakers of technology, fluent in the digital language of computers, video games and the internet (see, Prensky, 2006). The pedagogical issues of using digital technologies in early childhood education do not change rapidly, but it cannot be assumed that they remain constant either. Early childhood education may need to seriously consider the changing dispositions of children it works with. Further research is needed, (inter)nationally, into early childhood pedagogy and ICT (e.g. ways of effective digital technology integration in kindergarten classes).

\section{References}

Clements, D., \& Sarama, J. (2003). Strip Mining for Gold: Research and Policy in Educational Technology—A Response to “Fool's Gold”. Educational Technology Review, 11, 7-69.

Dennis, S. (2009). ICT for Practitioners. In H. Price (Ed.), The Really Useful Book of ICT in the Early Years (pp. 119-135). London: Routledge.

Flewitt, R. (2005). Conducting Research with Young Children: Some Ethical Considerations. Early Child Development and Care, 175, 553-565. http://dx.doi.org/10.1080/03004430500131338

Forman, G., \& Hall, E. (2005). Wondering with Children: The Importance of Observation in Early Education. Early Childhood Research and Practice, 7. http://ecrp.uiuc.edu/v7n2/forman.html.

Haugland, S. (1992). The Effect of Computer Software on Preschool Children's Developmental Gains. Journal of Computing in Childhood Education, 3, 15-30.

Haugland, S., \& Wright, J. (1997). Young Children and Technology, a World of Discovery. New York: Allyn and Bacon.

Heath, S., Charles, V., Crow, G., \& Wiles, G. (2007). Informed Consent, Gatekeepers and Go-Betweens: Negotiating Con- 
sent in Child- and Youth-Orientated institutions. British Educational Research Journal, 33, 403-417. http://dx.doi.org/10.1080/01411920701243651

Judge, S., Puckett, K., \& Bell, S. (2006). Closing the Digital Divide: Update from the Early Childhood Longitudinal Study. The Journal of Educational Research, 100, 52-60. http://dx.doi.org/10.3200/JOER.100.1.52-60

Keengwe, J., \& Onchwari, G. (2009). Technology and Early Childhood Education: A Technology Integration Professional Development Model for Practicing Teachers. Early Childhood Education Journal, 37, 209-218. http://dx.doi.org/10.1007/s10643-009-0341-0

Kennington, L., \& Meaton, J. (2009). Integrating ICT into the Early Years curriculum. In H. Price (Ed.), The Really Useful Book of ICT in the Early Years (pp. 4-24). London: Routledge.

Kervin, L., \& Mantei, J. (2009). Using Computers to Support Children as Authors: An Examination of Three Cases. Technology, Pedagogy and Education, 18, 19-32. http://dx.doi.org/10.1080/14759390802704014

Komis, V. (2004). An Introduction to Educational Applications of Information and Communication Technologies. Athens: New Technologies. (in Greek)

Labbo, L., Leu, D., Kinzer, C., Teale, W., Cammack, D., Kara-Soteriou, J., \& Sanny, R. (2003). Teacher Wisdom Stories: Cautions and Recommendations for Using Computer-Related Technologies for Literacy Instruction. The Reading Teacher, 57, 300-304.

Liu, M. (1996). An Exploratory Study of How Pre-Kindergarten Children Use the Interactive Multimedia Technology: Implications for Multimedia Software Design. Journal of Computing in Childhood Education, 7, 71-92.

Ljung-Djärf, A. (2008). To Play or Not to Play—That Is the Question: Computer Use within Three Swedish Preschools. Early Childhood and Development, 19, 330-339.

Ljung-Djärf, A., Åberg-Bengtsson, L., \& Ottosson, T. (2005). Ways of Relating to Computer Use in Preschool Activity. International Journal of Early Years Education, 13, 29-41. http://dx.doi.org/10.1080/09669760500048295

McCarrick, K., \& Li, X. (2007). Buried Treasure: The Impact of Computer Use on Young Children’s Social, Cognitive, Language Development and Motivation. AACE Journal, 15, 73-95.

McKenney, S., \& Voogt, J. (2010). Technology and Young Children: How 4-7 Year Olds Perceive Their Own Use of Computers. Computers in Human Behavior, 26, 656-664. http://dx.doi.org/10.1016/j.chb.2010.01.002

McKenney, S., \& Voogt. J. (2012). Teacher Design of Technology for Emergent Literacy: An Explorative Feasibility Study. Australasian Journal of Early Childhood, 37, 4-12.

Mikropoulos, A., \& Bellou, I. (2010). Educational Scenarios with Computers. Athens: Klidarithmos. (in Greek)

Morgan, A. (2010). Interactive Whiteboards, Interactivity and Play in the Classroom with Children Aged Three to Seven Years. European Early Childhood Education Research Journal, 18, 93-104. http://dx.doi.org/10.1080/13502930903520082

Morgan, A., \& Kennewell, S. (2005). The Role of Play in the Pedagogy of ICT. Education and Information Technologies, 10, 177-188. http://dx.doi.org/10.1007/s10639-005-2998-3

NAEYC-FRC (2012). Technology and Interactive Media as Tools in Early Childhood Programs Serving Children from Birth through Age 8. http://www.naeyc.org/files/naeyc/file/positions/PS_technology_WEB2.pdf

Nikolopoulou, K. (2010). Methods for Investigating Young Children's Learning and Development with Information Technology. In A. McDougall, J. Murnane, A. Jones, \& N. Reynolds (Eds.), Researching IT in Education: Theory, Practice and Future Directions (pp. 183-191). London: Routledge.

Nikolopoulou, K. (2014). Educational Software Use in kindergartens: Findings from Greece. In C. Karagiannidis, P. Politis, \& I. Karasavvidis (Eds.), Research on e-Learning and ICT in Education. Berlin: Springer.

Nir-Gal, O., \& Klein, P. (2004). Computers for Cognitive Development in Early Childhood-The Teachers' Role in the Computer Learning Environment. Information Technology in Childhood Education, 1, 97-119.

Olney, I., Herrington, J., \& Verenikina, I. (2008). iPods in Early Childhood: Mobile Technologies and Story Telling. In Hello! Where Are You in the Landscape of Educational Technology? Proceedings of Ascilite Melbourne 2008.

http://www.ascilite.org.au/conferences/melbourne08/procs/olney.pdf

Parette, H., \& Blum, C. (2013). Instructional Technology in Early Childhood: Teaching in the Digital Age. Baltimore, MD: Brookes.

Parette, H., Quesenberry, A., \& Blum, C. (2010). Missing the Boat with Technology Usage in Early Childhood Settings: A 21st Century View of Developmentally Appropriate Practice. Early Childhood Education Journal, 37, 335-343. http://dx.doi.org/10.1007/s10643-009-0352-X

Plowman, L., \& Stephen, C. (2003). A “Benign Addition”? Research on ICT and Pre-School Children. Journal of Computer Assisted Learning, 19, 149-164. http://dx.doi.org/10.1046/j.0266-4909.2003.00016.x 
Plowman, L., \& Stephen, C. (2005). Children, Play and Computers in Preschool Education. British Journal of Educational Technology, 36, 145-157. http://dx.doi.org/10.1111/j.1467-8535.2005.00449.x

Prensky, M. (2006). Listen to the Natives. Educational Leadership, 63, 8-13.

Rosen, D., \& Jaruszewicz, C. (2009). Developmentally Appropriate Technology Use and Early Childhood Teacher Education. Journal of Early Childhood Teacher Education, 30, 162-171. http://dx.doi.org/10.1080/10901020902886511

Roskos, K., Burstein, K., You, B. K., Brueck, J., \& O’Brien, C. (2011). A Formative Study of an E-Book Instructional Model in Early Literacy. Creative Education, 2, 10-17. http://dx.doi.org/10.4236/ce.2011.21002

Segers, E., \& Verhoeven, L. (2002). Multimedia Support of Early Literacy Learning. Computers and Education, 39, $207-221$. http://dx.doi.org/10.1016/S0360-1315(02)00034-9

Shawareb, A. (2011). The Effects of Computer Use on Creative Thinking among Kindergarten Children in Jordan. Journal of Instructional Psychology, 38, 213-220.

Siraj-Blatchford, I., \& Siraj-Blatchford, J. (2006). A Guide to Developing the ICT Curriculum for Early Childhood Education. London: Trentham Books.

Stephen, C., \& Plowman, L. (2003). Information and Communication Technologies in Preschool Classrooms: A Review of the Literature. International Journal of Early Years Education, 11, 223-234. http://dx.doi.org/10.1080/0966976032000147343

Van Scoter, J. (2008). The Potential of IT to Foster Literacy Development in Kindergarten. In J. Knezek (Ed.), International Handbook of Information Technology in Education (pp. 149-161). London: Springer.

Verenikina, I., Herrington, J., Peterson, R., \& Mantei, J. (2010). Computers and Play in Early Childhood: Affordances and Limitations. Journal of Interactive Learning Research, 21, 139-159.

Yelland, N. (2005). Curriculum, Pedagogies and Practice with ICT in the Information Age. In N. Yelland (Ed.), Critical Issues in Early Childhood Education (pp. 224-242). Milton Keynes: Open University Press.

Yelland, N., \& Kilderry, A. (2010). Becoming Numerate with Information and Communications Technologies in the Twenty-First Century. International Journal of Early Years Education, 18, 91-106. http://dx.doi.org/10.1080/09669760.2010.494426

YPEPTH-P.I. (2003). Cross-Thematic Curriculum Framework for Nursery School. Athens: Pedagogical Institute. (in Greek) http://www.pi-schools.gr/programs/depps/

Zevenbergen, R., \& Logan, H. (2008). Computer Use by Preschool Children: Rethinking Practice as Digital Natives Come to Preschool. Australian Journal of Early Childhood, 33, 37-44. 